\title{
Freedom of Speech in the Context of Media and Democracy
}

\author{
Dr. Sadia Mahmood \\ Assistant Professor \\ Department of Mass communication, \\ University of Karachi \\ sadia.mahmood@uok.edu.pk \\ Dr. Masroor Khanam \\ Assistant Professor \\ Department of Mass communication, \\ Federal Urdu University Art's Science \& Technology Karachi. \\ masroor.khanam@fuuast.edu.pk \\ ORCID ID https://orcid.org/0000-0002-4272-7596
}

\begin{abstract}
It is easy to forget the basic values at risk when it comes to a busy journalist, editor, broadcaster or media owner everyday life. This paper unfolds globally accepted democratic media law norms and best practise models. It reviews widely recognised democratic broadcasting and democratic media standards as well as standards to prohibit or otherwise regulate media content. Time limits, shrinking budgets, restricted electronic and library resources, demanding managers, challenges with distribution and harsh media legislation, not to mention news topics which are frequently worried about reporters if not openly antagonistic, are part of news rooms and among studio limitation. This is a difficult workplace and journalists may easily lose sight of the broader picture. The overall picture is that journalists' work reflects how we human beings connect and how effectively our company works. The interaction concepts that apply to each other as people are implemented and apply to the interaction between wider social entities, such as the medium and government. You can learn a lot about the status and dedication of a nation through democratic, economic and social progress by looking at respecting its people and media.
\end{abstract}

Keywords: Media, Democracy, Speech, Government, Journalists. 


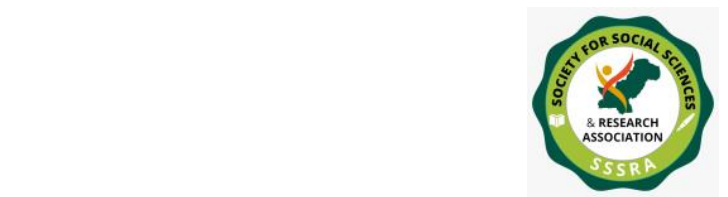

Pak. Journal of Int'L Affairs, Vol 4, Issue 1 (2021)

Freedom of Speech in the Context ...

\section{Introduction}

For the operation of a healthy democracy, the freedom of expression is crucial. Expression free from the danger of government reproach pushes the limits of the status quo and enables all types of advancement. Freedom of expression is safeguarded against government censorship by the legal status it holds, but also by the cultural values it holds in a free society. Today, both legal protection of freedom of expression and the social compact that uphold an atmosphere of respectful freedom of expression under danger. The laws governing how speech is conveyed or controlled are also shifting as the conventional public square, overseen and protected by federal legislation, shifts online into areas regulated by private companies. How should legal speech protection adapt to these new private fora that are powered by technology?

This paper examines the present environment of freedom of expression and the related information landscape and the dangers they face. In the middle of the present technological revolution, freedom of expression faces new problems as well. Today, news headlines regarding social media corporations using their algorithms for the spread of misinformation and against it. With this continuous discussion, freedom of expression became a major subject for protecting individual rights but it also highlighted issues about government, businesses, the press and everyone's duties in protecting the integrity of democracy. The decline in institutional confidence nowadays leads to the absence of accurate information and risks toppling the checks and balances system, allowing for unfettered misinformation. (Karppinen, \& Moe, 2014).

This tendency contributed to the notion of a post-truth period in which facts, particularly in connection with politics, are routinely contested. In addition, the role of political leaders in preventing the abuse of power in their bureaucracies, with a remarkable expansion of confidence in the media according to democratic principles, has now spread across the right and leftist parties. For the health of the information ecosystem it is necessary to combine expression choice with freedom of the press. Both modes of communication offer the opportunity for dissent, a critical check of hegemonic power from the dominant view. Freedom of expression and the press reinforce one other and rely on one another to maintain a balanced information ecology. If the public opinion swings to disinformation, corrected information may be aired in the news and public opinion can reverse the skewing towards advertising or sensationalism. (Phillips, 2011)

Above all, the two offer governmental power controls. Besides the importance of the right to disagree without being afraid of recompense, many now have the right to highquality information. As the information environment has evolved, people question where 


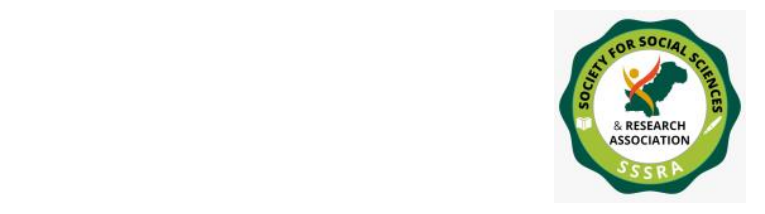

Freedom of Speech in the Context ...

to look for a trustworthy source of truth. Although not directly related to freedom of expression, it is complimentary - and sometimes contradictory - to the social contract under democracy that the capacity to access excellent information is. Many ask where the obligation to preserve the truth rests if the right to speak with regard to accuracy or quality is guaranteed by law. (Kovach, \& Rosenstiel, 2001).

\section{Free Speech Constitutive Rationales}

People matter; from time immemorial their achievements (errors or accomplishments) and experiences have moulded and impacted on the globe. But human civilization has only recently recognised the value of each human being's autonomy. The world community today recognises that people fundamentally matter: who we are and what we believe is important. What is the origin of this recognition? On which does it rely? And what is this recognition's distinctive feature?

\section{Equality}

Since the middle of the 20th century, the world community has taken on the idea of equality. In earlier century, slavery - the concept that one person can be possessed and live in bondage to another person-was viewed in virtually world-wide recognition as barbarian and in its whole an offence against humanity. After the mid $20^{\text {th }}$ century, contemplation on colonialism, apartheid and the Holocaust led many communities of countries, regardless of age, gender, breed, ethnicity, country, language, class, socioeconomic background or religion, to recognise that each human being is essentially equal. (Barendt, 2010).

\section{Dignity}

The acknowledgement of equality is inextricably connected with the respect of human dignity. One fundamental concept behind international human rights recognition is that every single person's dignity is respected regardless of distinctions between the individual and anybody else. The acknowledgement of the right to dignity of a person marks a substantial transformation in human relationships and a major break from previous practises and beliefs.

\section{Autonomy and Character}

Once the equality and intrinsic dignity of every human being is widely recognised, all persons must be allowed to grow and develop their characters to their utmost prospects. It 


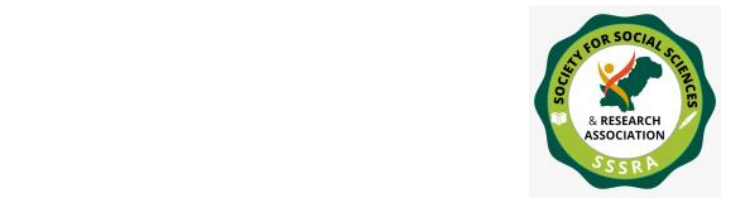

Freedom of Speech in the Context ...

is this acknowledgment, based on inherent dignity and equality, of your right to selffulfillment and autonomy, that underlines so many of the declarations globally accepted on fundamental human rights and freedoms. (SADC)

\section{Freedom of Speech in Different International Agreements on Human Rights}

It is necessary to examine how the extent of freedom of speech is defined by international human rights treaties to comprehend what is and what is not inside freedom. This section discusses the key provisions of several globally agreed agreements on the right to freedom of speech that lay forth the internationally agreed scope. Some elements have been touched on in the international instruments on human rights. (Lewis, \& Inthorn, \& Wahl-Jorgensen, 2005).

\section{The Universal Declaration of Human Rights}

Article 19 of the Universal Declaration of Rights states: 'Everybody's right, without interference, to freedom of opinion or expression, to access or communicate information and ideas through any media, regardless of borders, and to have freedom to express their views and views without interference.' Article 19 justifies considerable debate because there are in these paragraphs so many components of the right to freedom of speech. Importantly, the right:

- There are no qualifications available, for example citizenship and age

- There is no right for 'everyone," - the right to liberty of thought and manifestation is the right. In other words, people not only have the right to express their views on any subject (obviously covering thoughts, ideas and beliefs).

- Free 'expression' - all right. This includes nonverbals expression, such dance, mime, painting, photography as well as other nonverbals. This is wider than speech.

- The freedom to search, receive and communicate information and ideas is specifically included. Specifically This is a crucial component of the right, because everybody is entitled to get information. States that limit freedom of the media also violate their inhabitants' rights to easily obtain the facts.

- This freedom comprises of the ability to seek information and opinions "through any means." In the case of the press and media, this is a crucial pronouncement since it demonstrates that all forms of media are protected under the right to freedom of expression, including newspapers, radio, television, and the Internet. It is recognised 


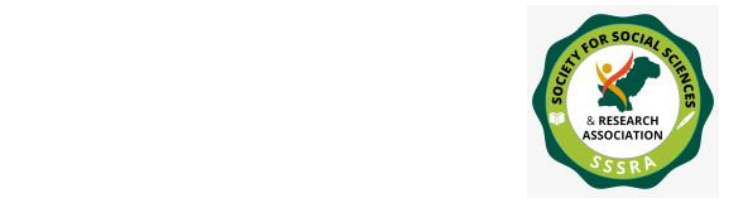

internationally as a global right that is not subject to or defined by nationwide limitations. In other words, it exists "without limits."

\section{The International Covenant on Civil and Political Rights}

A number of provisions of the Universal Declaration of Human Rights are elaborated in Article 19 of the ICCPR:

1. Everyone has the right to freely express his or her opinions without fear of being reprimanded.

2. The right to freedom of expression encompasses the freedom to seek, receive, and reveal any information or ideas of any kind, whether or not they are expressed vocally or in print, in the form of art, or by any other means he or she chooses, regardless of where he or she lives.

3. When exercising the rights mentioned in paragraph 2 of this article, the exercise of such rights is subject to additional obligations and responsibilities. As a result, it may be subject to various limitations, but only to the extent that is authorised by law and necessary:

(a) consideration for the privileges or standings of others;

(b) preservation of domestic safety or public directive, as well as public health or moralities.

Article 19 of the ICCPR justifies considerable examination, given that it shows some fundamental discrepancies between Article 19 of the Universal Declaration and its contents. Below are some particularly remarkable characteristics.

The most significant element is that, unlike the Universal Declaration, the Article 19 of ICCPR includes a clear declaration in section 3, on how governments could limit their right to freedom of speech. We are all aware that rights can be mutually exclusive. Examples include that the right to freedom of speech may unfairly be used:

(a) Ruin the reputation of an individual by publishing false defamatory comments and therefore violate the right to dignity of that person;

(b) Justifying the taking of a person's personal photos in violation of their right to privacy; 


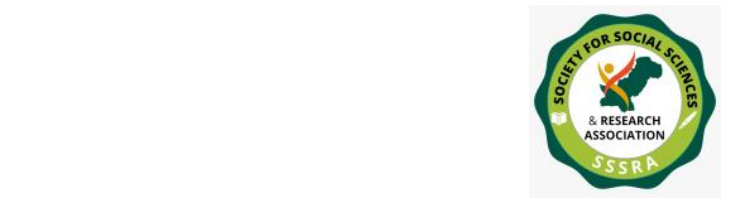

In response to this conflict of rights, Article 19 of the International Covenant on Civil and Political Rights recognises the State's right, in certain limited circumstances, to pass legislation restricting freedom of expression - in other words, where it is essential to protect the privileges or standings of others, as well as to safeguard national security, public order, public health, or moral principles. It is noteworthy that the term'required' is used in this context. It implies that the maintenance of reputation, national security, and public health are all jeopardised unless freedom of expression is limited in some manner. The standard that must be fulfilled is quite high. A number of international and regional human rights accords give protections for freedom of expression on par with each other. These regional accords include the European Union Convention for the Protection of Human Rights and Fundamental Freedoms and the African Charter on Human and People's Rights, to name a few of examples.

In accordance with the European Convention on Human Rights and Fundamental Liberties

According to Article 10 of the Convention of the European Union (EU) for the Protection of Human Rights and Fundamental Freedoms that was created in 1950, the freedom of expression is protected. The following are included in this article:

1. Everyone recognises and supports the right to free expression. This right encompasses the freedom of expression, information, and ideas to be received and transmitted without intervention by governmental authorities and without regard to national or international boundaries. No state is prohibited from forcing radio, television, or movie businesses to obtain licences under the provisions of this Article.

2. In the securities of national safety, territorial integrity, or community certainty in the event of disorder or crime, in order to protect health or moral rights, and for $\mathrm{p}$, as it carries with it duties and responsibilities, exercise of such freedoms can be subject to such formalities and conditions as are required by law and are necessary for the sake of democracy, The two very significant factors are:

In paragraph 1, the Right does not expressly preclude countries from need broadcasting, television and cinema broadcasting permits. In our opinion, the authorisation of broadcast 


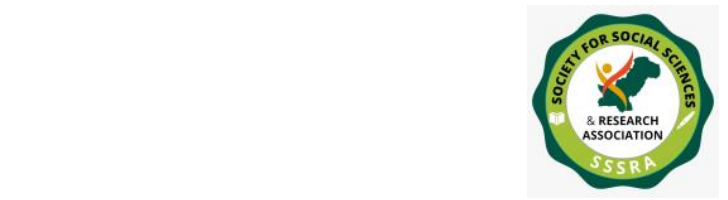

Freedom of Speech in the Context ...

media alone is not a danger to freedom of speech. In fact, since broadcasting media use scarce and finite natural resources in Africa - the spectrum of radiofrequencies (unlike cable media which in Africa are not widespread) - licencing is essential in order to avoid the inevitable interference with frequencies, resulting in the absence of public broadcasting media. Unfortunately, though, several nations of South Africa have to have licences to manufacture print media. It should be noted that print media licences are not covered by Article 10(1) of the EU Convention.

The rather complete list of allowable limits on the freedom of speech of States is provided for in Article 10(2) of the EU Convention. These are critically subjected to the general test of 'necessary' constraints in a democratic society. The list of limits authorised, for example, is larger than the ICCPR, and covers sensitive information with protection of the judiciary's authority and impartiality. (Brettschneider, 2012).

\section{Definition of the Media}

The term "media" refers to a wide category of material that is given to the general public or portions of the general public through a variety of channels rather than through a single organisation. The term "media" is used frequently. Only a few of the topics covered by the news media include: news and politics, business and current events; entertainment; driving; gardening; religion; home décor; fashion; cuisine; celebrity and lifestyle; and driving and driving safety. In addition, these problems are debated in a number of forums around the country. Traditional media such as newspapers, periodicals, radio, and television come to mind when one thinks of the word "media." Now that isn't the case any longer. There are a variety of platforms that fall under the category of 'new media,' including web-based platforms such as websites and mobile devices such as mobile television or the ability to view news headlines on your cell phone. It is only possible for internet-based media to be electronic copies of the printed media that are readily available. For example, a paper's website may include an electronic version of that daily journal, or these media may feature non-hardcopy original material that has not been previously published. (Kenyon, 2014)

With the advent of new media, the method in which citizens and the media communicate is changing. Social networking sites such as Twitter and Facebook have played a significant role as news and information providers in countries with severe censorship laws. The Arab upheavals of the last several years are the most notable example. The terms 'the media' and 'the press' are frequently used interchangeably. The word "the press" should be considered as a subset of "the media" when discussing the media and 


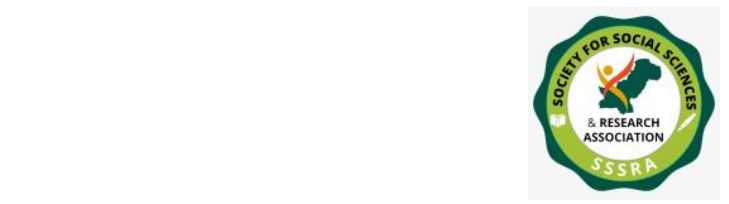

freedom of the press, but it should not be confused with the phrase "the media." Although there is an obvious association between news media, whether printed or electronic, and the phrase 'the press,' i.e. news media, there are many different types of media that fall under the umbrella term 'the press,' which includes state media, public media, commercial media, and even some forms of grassroots community media. The importance of these inequalities in judging the role of the press in particular, and the function of the media in general, cannot be overstated.

\section{The Press's Main Role}

Academic critics frequently describe the media or the press as "specific actors opposing power agencies on behalf of the public" and "make a stance among government agencies and the people" by media organisations. This is only true, of course, to some degree since some media sources (press, radio, or otherwise) are basically part and parcel of government, and hence no function that does not support government can or will play. Nonetheless, a robust and independent media, working in tandem with other institutions of civil society, may be able to exert mutually beneficial pressure on the government to support democracy and socio-economic development. In the words of media critic and researcher Masudul Biswas, "political involvement" is the primary goal of independent media outlets. It is linked to one of the most important justifications for the expression freedom in that the free flow of material and interchange of concepts are beneficial to democracy because they improve the efficiency and effectiveness of democratic government decision-making while also increasing transparency and answerability, and providing citizens with the opportunity to make conversant policy adoptions. A variety of additional tasks must be performed by the press to fulfil the crucial goal of contributing to 'meaning' democratic participation. These are the following items. (Zuboff, 2019)

\section{Detective of the Press}

However, the difference between public reporting and journalist inquiries in misconduct in the management of public affairs is investigated separately here in order to prevent repeats. The detective's function is essential in the obligation of the press as a public watchdog. The press is able to reveal wrongdoings by the public authorities when correspondents are well-trained and have access to trustworthy evidences. In order to divert public cash and other public resources for personal gains or diversions, this means cheating or bribing authorities in order. The media immerse itself in exceptionally long, thorough and deep investigational journalism - including nepotism, corruption, frauds, or any other type of crime - this 'defaulty media role' is proven by how public authorities (even private officials) reveal massive systemic wrongdoing. For any investigative 


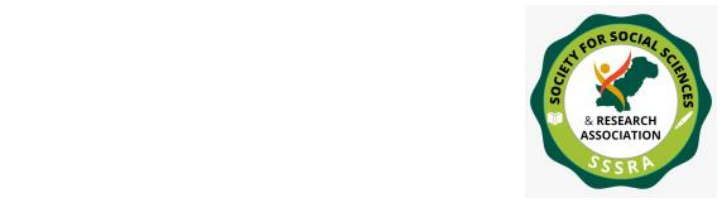

Freedom of Speech in the Context ...

activities, the veracity of these assertions depends on the work of more than one reporter and the support from the media or the entire media (whether broadcast or printed). In the ability and willingness of the media and other media to participate in investigative journalism to take action against corrupt public figures, even if it's because of the intolerable pressure placed on the police and prosecuting authorities as a result of the resulting publicity, law enforcement and prosecution authorities are crucial. (Nordenstreng, 2007).

\section{The Press as an Educator}

The press also has an educational function in society in general. This is possible on a variety of levels. For example, broadcasters can broadcast basic education resources for children to educate alphabets, colours or animals and can frequently help promote early childhood development. Print media sources may provide additional education materials for school students to enhance secondary education. Similarly, broadcasters can offer programmes aimed for tourists of history, science and even mathematics. Nevertheless, learning is considerably broader than just formal education and a general education function may be played by the press. The media (press or internet) may educate adult people on a wide range of educational questions, such as nutrition, health, fundamental money management and budgeting, agricultural development, childcare etc. (Mitchell, 2018)

\section{The Press Promotes Egalitarianism and Good Governance}

In addition, the press can perform the function of the advocate for democracy and good government linked to its broad educational mission, but more contentiously. The job is contentious since the press seeks to advocate and to report impartially. The press commented on current concerns and advocated greater democratic procedures and good governance in this capacity. In this position of advocacy, the media is firmly on the side of the common person who can improve or deteriorate in his life depending on the exercising of governmental authority. This job of advocacy is thus intimately related to the role of watchdog in the press. The press will not just cover what is going, but also what should happen. The press has practically been compelled to perform this function in many developed nations since improvements to fundamental human lives are not possible without democratic processes and effective administration.

This democratic advocacy duty is illustrated by the press's election function. The media can urge public officers to organise free and fair elections, in order to strengthen democratic processes and report on electoral issues (e.g. elections, political parties and 


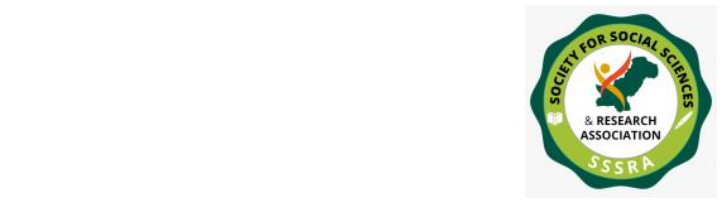

Freedom of Speech in the Context ...

tactics). For example, in this position, the press may tell people how democratic elections should be held. Information can be given by the press on, among alia, the relevance of the up-to-date ballot paper, electoral observers, multiparty officers at various polling stations, the security of the polling box, the free electoral instruction and the role of the media, especially public radio. In other words, the press may also reflect a democratic norm that should hold public leaders responsible in an election. The press therefore informs the public that public leaders are responsible for their acts. The press can also play a role in the promotion of democracy in the other areas:

- The administration is clean against bribery and nepotism.

- Adequate use of public resources vs waste and maladministration.

- Providing police and public security vs public violence, especially when the security or intelligence forces are involved.

- Economic and social growth vs increasing unemployment and poverty.

- Increase living standards in general compared to blatant inequalities and rich disparities.

- Public services responsive and directed against burgeoning and egotistic bureaucracy.

- Transparency, and accountability vs secrecy, disregard and suppression.

Importantly, not just the government will target news and comments in a media that plays a democratic advocacy role. Many developing nations do not always adhere to fundamental standards in the job, health and safety at work, environmental or other matters, businesses (including subsidiaries for major multinationals) and other private sector enterprises. Action by corporations and other private sectors beyond national or international norms that might harm persons, communities, or the environment has to be pointed out in the press. In the same spirit, international organisations such as the IMF, the World Bank and the World Trade Organization may and frequently have major economic implications for developing nations. A advocacy press should be in a position to bring out to the public what a fair trade system for exports and imports in the country would look like, for example. (Zuckerberg, 2018)

\section{The Press as a Driving Force for Democracy and Progress}

However, when the press is able to simply perform its main job of reporting on topics of public concern, it may serve as an advocate for transparency, openness, and accountability in the public arena. Businesses and government officials (even those in totalitarian regimes) do not want to be associated with negative publicity. Natural to some extent, a government may strive to offset negative news coverage by restricting press freedom, both legally and illegally. However, this is seldom a long-term sustainable 


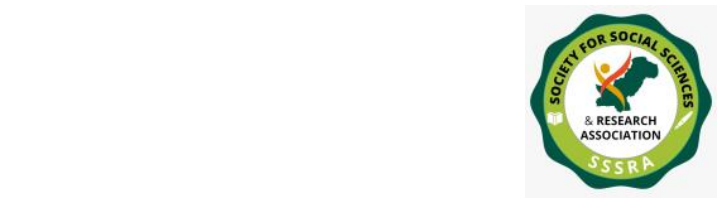

Freedom of Speech in the Context ...

response, as it is typically just intended to reduce the public's faith and support for the government. If the press is capable of performing any or all of the aforementioned functions, it has the potential to serve as a catalyst for democracy and progress, assisting in giving meaning to public participation. It is the people's endorsement of a press that correctly reports on public issues and provides trustworthy news and information on such issues. As public support for government grows, governments are under increasing pressure from the public to be more accessible and responsible, as well as to collaborate with the media rather than against it. There will be a role for the media when administrations learn to retort correctly to media censure, allowing for a virtuous circle of increasingly complicated dialogues between the government and the press to take place. Therefore, the government believes that independent media is an essential tool for communicating with the public about its policies and activities, as well as for measuring its own popular standing and support among the general population. When considering the press as a viable catalyst for democracy and growth, it is important to remember that certain African governments, following independence, have intentionally used the broadcasting: as a method of internal consolidation, development, and authoritarian supervision, among other things.

According to official rhetoric, expanding the reach of traditional media into rural regions will help to spur growth and technological dissemination. We all know that the press controlled by the government isn't the model we're talking about when it comes to the "press as catalyst for democracy and development." The greater the strength of the media in a particular country, the more it will be able to achieve its numerous obligations as an observer, investigator, educator, champion of good ascendency, and even a catalyst for development and democracy in that country. The greater the number of these tasks that the press can perform, the greater the amount of information that the public receives on topics of public importance. The better educated the public is, the more accountable the public is, and the more linked the public is to government, business, and even the civic community in an informed way (via the ballot box, consultations, and other means of communication) (via vote box, or through consultations or other contacts). Governments with informed citizens are generally able to make focused decisions since there is a open movement of information and concepts that can be accessed by governments in order to improve the efficiency of their operations. (Wolfensohn, 2002)

\section{Attacks on Democratic Press Freedom}

Some of the world's leading democracies no longer rely on fair news and information for substantial portions of the population. This is not because journalists, like totalitarian situations, are put into prison. Instead, more sophisticated measures have been made to 


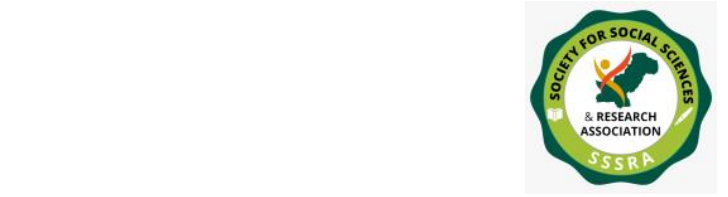

Freedom of Speech in the Context ...

shock the media's independence. Common methodologies include changes in ownership supported by the government, controlling and monetary pressure, and community reporting by honest media. Governments have also proactively supported sympathetic outlets by means such as profitable government contracts, good regulatory choices, and preferential access to state information. The aim is to ensure that the press serves those in power, not the people.

These emerged now conjunction to the populist right-wing, which in many democratic countries has weakened essential liberties. Populist leaders believe that the nation's interests - as they understand it — must overwrite democratic ideals like press freedom, openness and open discussion against liberal elites and ethnic minority whose allegiance they dispute. In the last five years, 19 percent (16 nations) of Freedom House Freedom's Freedom in the World report have seen a drop in press freedom rankings. This is consistent with a fundamental finding of freedom in the world - the reduction of political rights and civil freedoms in general for democracies. It has sadly become evident that even though democratic government has been in place for decades. (Kenyon, Svensson \& Edström, 2015).

The Government of Viktor Orbán in Hungary and the administration of Aleksandar Vucic in Serbia were quite successful in snuffing out criticism journalism and setting the stage elsewhere for populist movements. Both leaders have consolidated their media holdings. Almost $80 \%$ of the media are controlled by government friends in Hungary, where the trend has progressed even farther.

Progovernment media cultivation is expanding to neighbouring countries. A video clip that attempts to link with Russia's to buy the major national newspaper was taken by the head of the Austria's Freedom Party, which became a government coalition part in that country. Score decreases associated with economic media manipulation-including situations where government advertising is directed to favourable sources or encourages business friends to purchase critical ones-were in Europe in the recent 5 years more prevalent than in other world areas. Such influencing besides intervention are a comparatively new occurrence and since the collapse of Berlin Wall 30 years ago, press freedom has typically been strongly supported. (Masudul, 2009)

\section{Sparking a Global Downturn}

The deterioration of world freedom of the press is strongly associated with Freedom House's larger fall in democracy over the last 13 years. Even when the leadership of a nation has an anti-democratic bent, suppression of the media is a significant signal that 


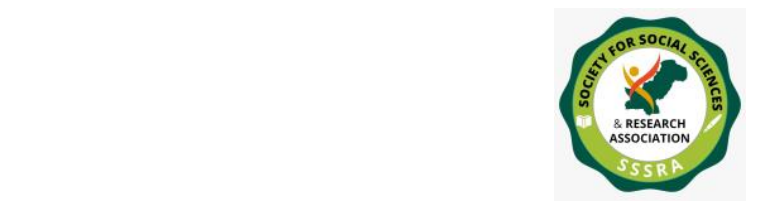

Freedom of Speech in the Context ...

other governmental privileges and public freedoms are in jeopardy. Media independence attacks often come as a result of new or incumbent leaders' seizures of power or the attempts of established regimes to break down perceived threats to their authority. In the last years, nations previously identified as Not Free in Freedom House's Freedom in the World report were more likely to have deterioration in their freedom of media rankings, $28 \%$ of which were not free. In part, there was almost as much chance for free countries that press freedom would diminish, as this reflects the instability of these midlevel actors and their complicated influences. The fall in worldwide press freedom has been driven by the deteriorating records in not free nations, together with the bad tendency of free countries. (Michael, 1994)

While populist democratic leaders are struggling to secure their gains and build on them through press domination, with any infringement of their media supremacy threatening to disclose authorised errors or degrading approved stories. In 2018 Russia, the government blocked the popular Telegram message app after the firm refused to give the security agencies its encryption keys. In Cameroon for the most part past year, internet services in the resident Anglophone area have been shut down; demonstrations have been heavily reacted and an upsurge has been a result of longstanding prejudice against the great Anglophone minority. In Myanmar, the court overlooked obvious evidence that two Reuters journalists were trapped to stop their investigations of military crimes against Rohingya minority, and that they were recently parsed, they were not exonerated. In the course of a failed trial, two Reuters journalists were punished.

\section{Key Findings}

Media freedom has degraded in the last decade throughout the world. Populist leaders have supervised systematic efforts to galvanise independence in the media sector in some of the most prominent democracies of the world. While worldwide challenges to freedom of the media are genuine, and concern themselves, they are really harmful in their influence on the status of democracy. However, experience has shown that freedom of the press may recover if opportunities are provided following long periods of persecution. Nobody can ever erase the underlying yearning for democratic freedoms, especially the availability to honest and factual news.

\section{Conclusion}

In the democratic process, freedom of expression is a fundamental virtue. It guarantees that individuals may talk, discuss and explore ideas. The right of people to find knowledge that is vital to people and communities, without censorship or punishment,

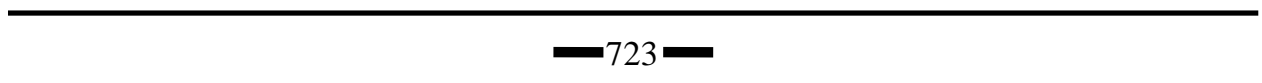


and to share it with others. Freedom of speech promotes the growth of informed citizens and voters through the media and through public discussion - online and offline. Clearly, freedom of expression and especially of the press is the medium used by most people throughout the world to receive news and information. Connaissance is power. Power. Print, online or on TV or radio: individuals cannot understand completely what is going on in their communities or democracies without a free interchange of information, and thus can not engage in meaningful ways. In the framework of press freedom fighting in the country, among especially in the masses, broadcasting has traditionally been a neglected subject. Just lately (in the last 15 to 20 years) governmental monopolies have been abolished on the airwaves (both radio and TV) and a more varied transmission has begun to develop. This research adds to this trend by establishing the aspect of democratic regulatory media and by examining the regulatory environment for broadcasting in each chapter of each country to see whether it complies with worldwide best practises or not. 


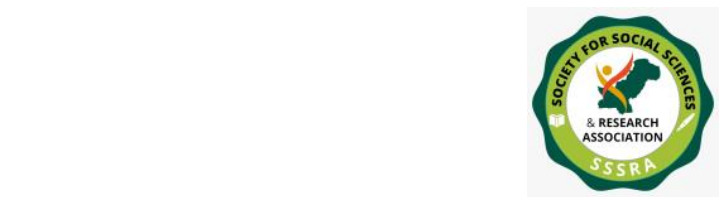

\section{References}

Barendt, E. (2010 [1985]). Freedom of speech. Oxford Scholarship Online, chapter 11. DOI: 10.1093/acprof:oso/9780199225811.001.0001.

Brettschneider, C. (2012). When the State Speaks, What Should It Say? How

Democracies Can Protect Expression and Promote Equality. Princeton: Princeton University Press.

http://www.echr.coe.int/NR/rdonlyres/D5CC24A7-DC13-4318-B457-5C9014916D7A/0/ ENG_CONV.pdf

http://www.wunrn.com/reference/pdf/American_convention_Human_Rights.PDF

https://www.facebook.com/notes/ mark-zuckerberg/a-blueprint-for-content-governanceand-enforcement/10156443129621634/?hc_location=ufi.

Karppinen, K. and Moe, H. (2014). 'What We Talk about When We Talk about "The Market": Conceptual Contestation in Contemporary Media Policy Research', Journal of Information Policy 4(2014): 327-341.

Kenyon, A. (2014). 'Assuming Free Speech'. The Modern Law Review. 77(3): 379-408

Kenyon, A., Svensson E-M. and Edström, M. (2015). Building systems for freedom of expression. Paper presented at NordMedia 2015, Copenhagen, Aug 11-13.

Kovach, B. and Rosenstiel, T. (2001). The Elements of Journalism: what news people know Hubble and the public expect Hubble. New York: Crown.

Lewis, J. M. W., Inthorn, S. and Wahl-Jorgensen, K. (2005). Citizens or consumers: What the media tell us about political participation. Maidenhead: Open University Press.

Masudul B., (2009)‘Media Freedom, Governance and Civil Society’, Conference Paper, 2009, 3-10. Available at http://www.allacademic.com/one/prol/prol01/index.php?cmd= prol01_ search\&offset=0\&limit=5\&multi_search_search_mode=publication\&multi_searc h_publicati on_fulltext_mod=fulltext\&textfield_submit=true\&search_module=multi_search\& 


\section{search $=\mathrm{Se}$}

arch\&search_field=title_idx\&fulltext_search=Media+Freedom $\% 2 \mathrm{C}+$ Governance + and + Civ il+Society

Michael B., (1994) 'Civil Society and Political Transition in Africa'. Institute for Development Research Reports, 11(6), 2. Available at http://worlded.org/docs/Publications/idr/ pdf/11-6.pdf

Mitchell, A., (2018) et al. "Distinguishing Between Factual and Opinion Statements in the News." Pew Research Center, 18 June 2018, https://www. journalism.org/2018/06/18/distinguishing-between-factual-and-opinionstatements-in-the-news/.

Nordenstreng, K. (2007). 'Myths about press freedom', Brazilian Journalism Research: Journalism Theory, Research and Criticism 3(1): 15-30.

Phillips, A. (2011). 'Unwilling as Journalists 'Sources'. Transparency and the New Ethics of Journalism', in Franklin and Carlson: Journalists, Sources, and Credibility. New Perspectives. New York: Routledge.

SADC, Regional Indicative Strategic Development Plan, Chapter 2 [online]. Available at http://www.sadc.int/index/browse/page/108

Wolfensohn, J. (2002) 'The Right to Tell: The Role of Mass Media in Economic Development', World Bank Institute Report, World Bank, 5-15

Zuboff, S.. (2019) The Age of Surveillance Capitalism: The Fight for a Human Future at the New Frontier of Power. Public Affairs.

Zuckerberg, M. (2018)“A Blueprint for Content Governance and Enforcement.” Facebook, 15 Nov., 